\title{
TANGGAPAN MASYARAKAT DESA WONOREJO KECAMATAN MANGKUTANA KABUPATEN LUWU TIMUR TERHADAP DAKWAHTAINMENT ISLAM ITU INDAH DI TRANS TV
}

\author{
Audah Mannan, Fatmawati \\ Fakultas Dakwah dan Komunikasi UIN Alauddin Makassar \\ Email: audah.mannan@uin-alauddin.ac.id
}

\begin{abstract}
:
The main issues of this research are 1) Community responses from Wonorejo Village, Mangkutana Subdistrict, East Luwu Regency to Da'wahtainment Islam itu Indah on Trans TV 2) Factors that encourage the public to watch the Islamic Da'wahwah program that is Beautiful on Trans TV. The results of this study are; Demonstrating responses The people of Wonorejo Village are more interested in propaganda material that is 'akhlakul karimah' with a light and simple material delivery. Because, the material is more often found in everyday life. Factors that encourage the public to witness Islam itu Indah's propaganda programs on Trans TV are the delivery of interesting and easily understood propaganda material, the theme presented is very interesting to the viewer, the desires and needs of the community towards propaganda are very complex with themes related to daily life. That is akhlakul karimah.
\end{abstract}

Keywords: community, da'wahtainment, Islam itu Indah

\section{A. PENDahuluan}

Sebelum era digital, manusia mendapatkan informasi hanya melalui media cetak berupa majalah atau Koran. Seiring dengan perkembangan teknologi sekarang ini, munculah media massa elektronik yang dapat memberikan informasi dan hiburan yang lebih komplit. Salah satu media massa elektronik yang sangat berpengaruh dan kuat saat ini adalah televisi. Televisi juga merupakan paduan dari radio (broadcast) dan film (moving picture) ${ }^{1}$. Keunggulan yang dimiliki oleh media televisi adalah audiovisual, dimana televisi dapat dilihat dan juga didengar sekaligus. Televisi sebagai bagian dari kebudayaan audivisual yang merupakan medium paling berpengaruh dalam membentuk sikap dan kepribadian masyarakat secara luas. Hal ini disebabkan oleh pesatnya perkembangan jaringan televisi yang menjangkau masyarakat hingga ke wilayah yang terpencil sekalipun. Kultur yang dibawa oleh televisi dengan sendirinya mulai bertumbuh di masyarakat. Unsur esensial dari kebudayaan televisi berupa penggunaan bahasa

${ }^{1}$ Onong Uchjana Effendy Ilmu, Teori dan Filsafat Komunikasi (Bandung : PT. Citra Aditya Bakti, 2002), h. 174 
verbal dan visual, sekaligus dalam rangka menyampaikan sesuatu seperti pesan, informasi, pengajaran, ilmu dan hiburan.

Kehadiran televisi, dalam kehidupan masyarakat, telah mengubah pola pikir dan aktivitas kesehariannya. Televisi memiliki peran yang signifikan bagi seseorang, yang dapat terlihat dari persentase yang tinggi untuk menonton televisi. Bahkan, tidak jarang menonton acara televisi seperti menjadi kewajiban hingga mengalahkan salat yang merupakan kewajiban mendasar (sesungguhnya) bagi umat Islam. Hidup terasa kurang bila satu hari saja terlewatkan dalam menyaksikan acara televisi, terlebih yang digemari. Perkembangan industri media, terutama televisi seringkali dikaitkan dengan perkembangan masyarakat informasi. Dalam konteks masyarakat seperti ini, media televisi memiliki peran yang signifikan. Media adalah sarana komunikasi antar-berbagai subjek. Ia merupakan medium yang menjembatani komunikasi dengan seluruh anggota masyarakat. Dengan demikian media, dalam hal ini televisi, merupakan instrumen komunikasi yang sangat vital dalam masyarakat.

Televisi adalah sumberdaya yang terbuka bagi semua orang dalam masyarakat industri, dan semakin mengalami pertumbuhan di negara-negara berkembang. Ia juga sumber bagi pengetahuan popular tentang dunia dan semakin membuat kita menjalin kontak, meskipun melalui perantara, dengan cara hidup orang selain tinggal di tempat kita dilahirkan. ${ }^{2}$ Televisi yang merupakan perpaduan antara audio dan visual memang menjadi daya tarik luar biasa bagi setiap orang untuk menikmatinya. Keberadaannya sudah menjadi bagian yang tak terpisahkan dalam kehidupan masyarakat.

Program siaran yang bernuansa religi tersebut dapat dikategorikan sebagai syiar atau dakwah Islam, tetapi sekaligus juga sebagai hiburan, konsep inilah yang kemudian disebut dengan dakwahtainment. Dakwahtainment adalah untuk memenuhi kebutuhan masyarakat Islam merupakan bentuk tawaran pemenuhan kebutuhan kehidupan religiusnya. Tayangan dakwah ini merupakan ruang yang akan memudahkan masyarakat muslim untuk mengakses dan menemukan kajian-kajian keagamaan dengan lebih mudah, tanpa harus meninggalkan rumah, cukup dengan menonton televisi, semuanya sudah dapat tersedia. Sementara bila dilihat dari sisi industri budaya. Tayangan dakwahtainment adalah industri kreatif yang memang ditawarkan kepada pemirsa (masyarakat Islam) sebagai metode dan media dakwah yang kontemporer.

${ }^{2}$ Chris Barker, Studi Budaya Teori dan Praktik, Terj. Nurhadi (Yogyakarta: Kreasi Wacana, 2006), h. 275. 
Secara umum Desa Wonorejo adalah daerah dataran Rendah dan sedikit Daerah Perbukitan dan Rawa-Rawa. Sektor Pertanian Tanaman Pangan (Lahan Persawahan) merupakan lahan terluas yang ada di Desa Wonorejo, Sekaligus juga menjadi pusat Pemerintahan Kecamatan Mangkutana Kabupaten Luwu Timur. Desa Wonorejo di huni oleh berbagai suku (Etnis) yang antara lain : Suku Jawa, Toraja, Bugis, Batak, Pamona. Adapun suku yang dominan adalah suku Jawa. Agama yang di anut oleh Penduduk Desa Wonorejo adalah Islam dan Kristen.

Desa dengan kepadatan penduduk 371 orang perkilometer persegi dan berbatasan langsung dengan provinsi Sulawesi Tengah. Dengan perkembangan teknologi komunikasi dan informasi yang mulai merambah berbagai kalangan mulai dari anak-anak, Remaja dan dewasa yang menimbulkan berbagai dampak sosial. Keberagaman agama tidak menjadi penghalang masyarakat setempat untuk mendalami pengetahuan agama dan adanya sikap saling toleransi. Oleh karena itu, Peneliti ingin mengetahui respon masyarakat setelah menonton program tayangan Dakwahtainment Islam Itu Indah di Trans TV.

Program acara dakwahtainment "Islam itu indah" yang tayang di Trans TV layak untuk diteliti karena dari program acara tersebut banyak wawasan juga pengetahuan Islam yang disuguhkan. Tidak hanya tentang Islam yang monoton, akan tetapi lebih kepada implementasi dalam kehidupan sehari-hari untuk beragama yang lebih baik. Selain itu, banyaknya para pemirsa atau penonton yang tergerak hatinya ketika melihat acara tersebut juga menjadi faktor yang melatarbelakangi peneliti untuk melakukan penelitian terhadap program acara ini, untuk mengetahui strategi dan pesan dakwah yang disampaikan dari program acara tersebut.

Berdasarkan gambaran dan uraian di atas, maka pokok permasalahan dalam penelitian ini adalah "Bagaimana Pandangan Masyarakat di Desa Wonorejo Kecamatan Mangkutana Kabupaten Luwu Timur Terhadap Dakwahtainment Islam itu indah di Trans TV".Dari pokok masalah tersebut, penulis merumuskan permasalahan sekaligus merupakan pembahasan permasalahan yang akan diteliti yaitu:

1. Bagaimana tanggapan Masyarakat Desa Wonorejo Kab. Luwu Timur terhadap Dakwahtainment Islam Itu Indah di Trans TV?

2. Faktor-faktor apa yang mendorong masyarakat untuk menyaksikan program Dakwahtainment Islam Itu Indah di Trans TV ? 


\section{B. TINJAUAN TEORETIS}

\section{Televisi Sebagai Media Komunikasi Massa}

Pengertian komunikasi massa media televisi ialah proses komunikasi antara komunikator dengan komunikan (massa) melalui sebuah sarana, yaitu televisi. Dalam komunikasi massa media tersebut, lembaga penyelenggara komunikasi bukan secara perorangan, melainkan melibatkan banyak orang dengan organisasi yang kompleks dan pembiayaan yang besar. Media televisi bersifat transitory (hanya meneruskan), maka pesan-pesan yang disampikan melalui komunikai massa media tersebut hanya dapat didengar dan dilihat sekilas. Pesan-pesan televisi bukan hanya didengar, tetapi juga dapat dilihat dalam gambar yang bergerak (audio visual). ${ }^{3}$ Dimana secara logis komunikasi massa adalah pesan-pesan yang di produksi secara masal dan disampaikan secara luas dan heterogen.

Sifat komunikasi massa media televisi yang transitory (hanya meneruskan) yaitu : (1) isi pesan yang akan disampaikannya harus singkat dan jelas, (2) cara penyampaian kata per kata harus benar, (3) intonasi suara dan artikulasi harus tepat dan baik. ${ }^{4}$

Menurut Elizabeth-Noelle Neuman, ada empat tanda pokok komunikasi massa antara lain:

1. bersifat tidak langsung, artinya harus melalui media teknis.

2. bersifat satu arah, artinya tidak ada interaksi antara peserta-peserta komunikasi (para komunikan)

3. bersifat terbuka, artinya ditujukan kepada publik yang tidak terbatas dan anonim.

4. mempunyai publik yang secara geografis tersebar. ${ }^{5}$

Komunikasi massa itu sendiri berkembang seiring dengan digunakannya alat-alat mekanik yang mampu melipat gandakan pesan-pesan komunikasi lebih tepatnya setelah mesin cetak ditemukan oleh Johan Gutenberg pada awal abad 20. Gejala pengembangan komunikasi massa makin meluas ketika radio dan film digunakan sebagai media komunikasi massa disusul tumbuhnya industri televisi pada pertengahan abad 20 era tahun 1950-an. Komunikasi massa merupakan jenis komunikasi yang menggunakan media massa untuk menyampaikan pesanpesannya. Menurut Berlo bahwa kata massa diartikan "Meliputi semua orang yang menjadi sasaran alat-alat komunikasi massa atau orang-orang pada ujung lain dari saluran". Massa

\footnotetext{
${ }^{3}$ Wawan Kuswandi. Komunikasi Massa Sebuah Analisis Media Televisi. h.16.

${ }^{4}$ Wawan Kuswandi. Komunikasi Massa Sebuah Analisis Media Televisi, h. 18

${ }^{5}$ Jalaludin Rahmat. Psikologi Komunikasi, h.189
} 
mengandung pengertian orang banyak dan mereka tidak harus berada di lokasi tertentu yang sama, mereka dapat tersebar di berbagai lokasi yang dalam waktu yang sama atau hampir bersamaan dapat memperoleh pesan-pesan komunikasi yang sama ${ }^{6}$.

Pengelola penyiaran tidaklah sepatutnya mengabaikan salah satu dari tiga pilar utama ini. Program yang baik akan senantiasa mengikat pemirsa untuk mengikuti setiap mata acara yang disajikan, demikian pula dari segi teknis di mana pemirsa selalu menuntut kenyamanan dalam setiap tayangan yang disajikan. Gambar yang tidak jelas menyebabkan pemirsa segera beralih ke acara yang lainnya. Pilar ketiga dari tiga pilar utama tersebut ialah aspek pemasaran, dalam hal ini audiens dipahami melalui pendekatan ilmu pemasaran karena audiens adalah konsumen yang memiliki kebutuhan terhadap program siaran (produk stasiun televisi) ${ }^{7}$.

Televisi siaran merupakan media komunikasi massa karena memenuhi unsur-unsur yang terdiri dari sumber (source), pesan (message), saluran (channel), penerima (receiver) serta efek $($ effect $) .{ }^{8}$ Pada saat ini televisi merupakan salah satu media komunikasi yang banyak dibutuhkan masyarakat karena televisi memiliki sifat media yang khas sebagai media pandang dengar (audio-visual) sifat ini menjadikan keunggulan media televisi mampu menyampaikan pesan yang lebih hidup. Segala informasi seperti isu sosial politik, ekonomi, budaya, hukum, kriminalitas, olah raga sampai dengan masalah gosip para public figure, kuis, permainan (games) semuanya ditayangkan di media televisi dengan beragarn kreasi pengemasan program acaranya.

Media televisi pada hakekatnya lahir karena perkembangan teknologi. Penemuan bermula dari ditemukannya elecctrische telescope sebagai perwujudan gagasan dari seorang mahasiswa di Berlin (Jerman Timur) yang bernama Paul Nipkov, untuk mengirim gambar melalui udara dan satu tempat ke tempat lain. Hal ini terjadi antara tahun 1883-1884. Akhirnya Nipkov diakui sebagai "bapak" televisi. ${ }^{9}$ Saat ini bisa dikatakan bahwa televisilah yang menjadi media komunikasi massa paling populer. Studi tentang televisi pun banyak dilakukan. Karakteristik televisi yang memiliki jangkaun siar luas dan dapat memberikan efek yang besar pula menjadi daya tarik tersendiri untuk diteliti. Seperti yang diungkapkan oleh Milly Buonanno:

\footnotetext{
${ }^{6}$ Wiryanto, Pengantar Ilmu Komunikasi (Jakarta: PT Gramedia Widiasarana Indonesia, 2004).h. 66

${ }^{7}$ Morisson, Manajemen Media Penyiaran, Strategi Mengelola Radio \& Televisi, h. 163

${ }^{8}$ Wiryanto, Pengantar Ilmu Komunikasi h. 67

${ }^{9}$ Wawan Kuswandi. Komunikasi Massa Sebuah Analisis Media Televisi (Jakarta: Rineka Cipta, 1996), h 5-
} 
The thing that brought many to study television in the first place, namely a popular reach, commercial scale, political power, and cultural significance that made The Tube a metonym of society as a whole, has passed ${ }^{10}$.

Secara teknis televisi dapat diartikan sebagai sebuah alat penangkap siaran bergambar. Istilah televisi (television) merupakan suatu kata yang berasal dari gabungan kata tele (bahasa Yunani) yang berarti jauh dan vision (bahasa Latin videra) artinya melihat/memandang. Jadi secara harfiah, televisi berarti memandang dari jauh. Tepatnya, televisi ialah memandang peristiwa dari jauh dalam waktu yang bersamaan ${ }^{11}$.

Fungsi televisi secara umum adalah sebagai berikut:

\section{a. Fungsi Penerangan (The Information Function) \\ b. Fungsi Pendidikan (The Educational Function) \\ c. Fungsi Hiburan (The Entertainment Function). ${ }^{12}$}

Media massa yang memiliki fungsi hiburan. Hal ini jelas sebagai salah satu fungsi yang lebih bersifat human interest. Maksudnya, agar pemirsa tidak merasa jenuh dengan berbagai isi pesan yang disajikan oleh media. Selain itu, fungsi menghibur media massa juga memiliki daya guna sebagai pelarian pemirsa terhadap suatu masalah. Bahkan, justru karena fungsi hiburan ini orang/masyarakat mengkonsumsi media massa.

Dauglas Kellner mengungkapkan bahwa tontonan audio visual sebagai elaborasi dari budaya media telah membantu merangkai kehidupan sehari-hari, mendominasi proyek-proyek hiburan, membentuk opini politik dan perilaku sosial, bahkan memberikan suplai materi untuk membentuk identitas seseorang. ${ }^{13}$

\section{Dakwah melalui Media Televisi}

Dakwah memiliki pengertian yang luas, dakwah tidak hanya berarti mengajak dan menyeru umat manusia agar memeluk Islam. Dakwah juga berupaya membina masyarakat Islam menjadi masyarakat yang lebih berkualitas (khairu ummah) yang terbina atas dasar tauhid serta ketinggian ajaran Islam.

${ }^{10}$ Milly Bounnanoo. The Age of Television Experiences and Theories. Book Review by John Hartly. (International Journal of Communications: 2009), h. 2

${ }^{11}$ Sofiah. Komunikasi Media Film dan Televisi. (Surakarta: UNS Press, 1993), h. 47

${ }^{12}$ Onong Uchjana Effendy, Televisi Siaran Teori dan Praktik (Bandung: Mandar Maju, 1993), h. 24.

${ }^{13}$ Douglas Kellner, Media Culture: Cultural Studies, Identity anPolitics between The Modern and Postmodern (New York: Routledge, 1995), h. 230 
Kata dakwah berasal dari bahasa Arab دعا yang berarti طلب menyeru, meminta, menuntun, menggiring atau memanggil, mengajak orang lain supaya mengikuti, bergabung, memahami untuk memiliki suatu tindakan dan tujuan yang sama yang diharapkan oleh penyerunya $^{14}$.

Secara etimologis, dakwah berasal dari kata da'a yad'u da'watan (دعا- يدعو دعوة) yang berarti mengajak, memanggil, dan menyeru. Akar kata da'a dengan segala bentuk dan penerapannya di dalam al-Qur'an terulang sebanyak 212 kali. Adapun derivasinya dapat dipaparkan sebagai berikut: دعاه, (memanggilnya/meminta pertolongannya), دعاه الي الامر, (memberi motivasi kepadanya), دعاه فلا نا لـ له (memberinya nama), (makan baik kepadanya), دعا اليه, (mendoakan buruk).

Dakwah Islam adalah menyeru ke jalan Allah yang melibatkan unsur-unsur penyeru, pesan, media, metode yang diseru, dan Tuhan. Menurut al-Bahiy, dakwah Islam berarti merubah suatu situasi ke situasi yang lebih baik, sesuai ajaran Islam. ${ }^{16}$ Dalam dakwah terdapat dua dimensi besar:

Pertama, mencakup penyampaian pesan kebenaran, yaitu dimensi "kerisalahan" (bi ahsan al-qawl), merupakan tuntunan dari Q.S. al-Maidah: 67 dan Q.S al-Imran:104.

Dimensi kerisalahan dakwah mencoba menumbuhkan kesadaran diri (individu/masyarakat) tentang kebenaran nilai dan pandangan hidup secara Islam, sehingga terjadi proses internalisasi nilai-nilai Islam sebagai nilai hidupnya, dengan kata lain dakwah kerisalahan dalam prakteknya merupakan proses mengkomunikasikan dan menginternalisasikan nilai-nilai Islam, dalam hal ini (a). Islam merupakan sumber nilai, dan (b). Dakwah sebagai proses alih nilai.

Kedua, mencakup pengaplikasian nilai kebenaran yang merupakan "kerahmatan" (bi ahsan al-'amal), mengacu pada firman Allah Q.S. al- Anbiya':107.

Dakwah kerahmatan ini merupakan upaya mengaktualisasikan Islam sebagai rahmat (jalan hidup yang menyejahterakan, membahagiakan, dan sebagainya) dalam kehidupan umat manusia. Dengan begitu, kalau dalam dimensi kerisalahan dakwah lebih cocok sebagai

\footnotetext{
${ }^{14}$ Sad 'Ali Ibn Muhammad al-Qohthoniy.fiqhu al-da'wah fi shahîh al-Imam al-Buhkariy, Maktaba Syamela.

${ }^{15}$ Muhammmad Ismail Ibrahim (Al-Qaahira; Dar Al-Fikr, Al 'Arabi, TT), jilid I, h. 18. Lihat juga Muhammad Fath al-bayanuni, al Madzkhal ila Ilmi Da'wah (Madinah: Muassasah al-risalah, 1994) h. 20. Lihat juga, Ahmad Warson Munawwir, al-Munawwir Kamus Arab Indonesia (Yogyakarta: Pondok Pesantren AlMunawwir, Krapyak, 1984), h. 439.

${ }^{16}$ Aep Kusnawan, Komunikasi Penyiaran Islam (Cet. I; Bandung: Benang Merah Press, 2004), h. vii.
} 
"mengenalkan Islam", sedangkan dalam dimensi kerahmatan, dakwah merupakan upaya mewujudkan Islam dalam kehidupan. ${ }^{17}$

Dimensi kerisalahan terdapat dua bidang besar, yaitu (1) Tabligh dan (2) Irsyad, sedangkan dalam dimensi kerahmatan terdapat dua bidang besar juga, yaitu (1) Tadbir dan (2) Tathwir.

Salah satu di antara bidang dakwah kerisalahan adalah tabligh secara bahasa, yang berarti menyampaikan informasi atau berita (khabar). Dalam kelembagaan pendidikan tinggi dakwah Islam, kajian tentang ilmu dakwah adalah upaya mentransformasikan dan menginternalisasikan nilai-nilai Islam kepada umat yang sifatnya massal serta pendekatan keilmuannya pun komunikasi massa atau dakwah ummah.

Pertama, pembaharuan kemasan konsep dakwah di media televisi mengacu pada alQur'an dapat iidentifikasi sebagai panggilan (aktualisasi) iman (Q.S. al-Anfal/8:24), pencerahan agama (Q.S. Ibrahim/16:1 dan 5) dan proses masyarakat menuju kualitas "khairu ummah". Allah berfirman dalam (Q.S. Ali-Imran/3:110).

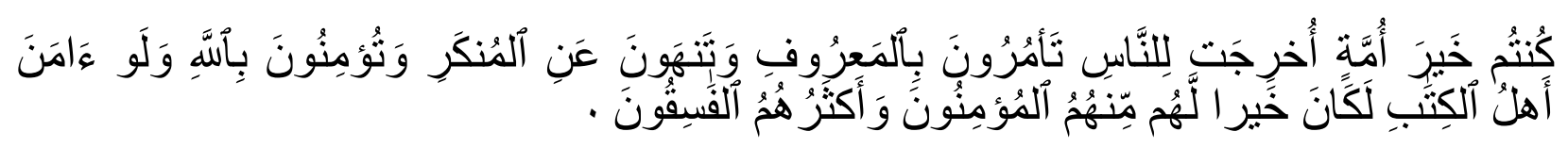

Terjemahnya:

Kamu adalah umat yang terbaik yang dilahirkan untuk manusia, menyuruh kepada yang makruf, dan mencegah dari yang mungkar, dan beriman kepada Allah. Sekiranya ahli kitab beriman tentulah itu lebih baik bagi mereka, di antara mereka ada yang beriman dan kebanyakan mereka adalah orang- orang fasik ${ }^{18}$

Upaya mewujudkan iman dan Islam dapat dilakukan dengan berbagai cara, antara lain melalui komunikasi dan penerangan agama (al-tabligh wal al bayan), pembudayaan dan sosialisasi nilai-nilai Islam dalam kehidupan masyarakat (al-amr bi al-ma'ruf), dan kontrol sosial terhadap segala bentuk kejahatan yang akan mengganggu dan merusak tatanan dan nilainilai Islam (al-nahy-u 'an al-Mungkar), keteladanan prilaku (qudwah hasanah), serta melalui pergerakan (harakah atau movement) dengan membangun organisasi yang kuat dan solid sebagai

\footnotetext{
${ }^{17}$ Aep Kusnawan, Komunikasi Penyiaran Islam, h. viii

${ }^{18}$ Departemen Agama, Al Quran dan Terjemahannya, (Semarang, Toha Putra, 2007).
} 
wadah bersama yang akan menghimpun dan memobilisasi kekuatan Islam untuk kemajuan dakwah. $^{19}$

Aktivitas dakwah dengan pembaharuan konsep dakwah di media televisi diharapkan mampu melahirkan perubahan yang berarti bagi kemajuan umat dan bangsa. Dakwah harus melahirkan umat yang utama atau umat yang unggul (khairu ummah). Umat yang terbaik adalah umat yang unggul, umat yang aqidah dan ibadahnya kuat. Hal ini dibuktikan dengan melakukan tiga hal yaitu amar ma'ruf, nahi mungkar, dan iman. Ketiganya dipahami Sayyid Quthub sebagai ciri atau karakter dasar umat Islam. ${ }^{20}$

\section{Dinamika Metode Dakwahtainment di Televisi}

Dakwahtainment didefinisikan sebagai suatu konsep yang memadukan penyebarluasan Islam dan bentuk-bentuk siaran hiburan yang tak terhitung banyaknya di dunia televisi, yang memungkinkan jutaan pemirsa di rumah menonton. Dakwahtainment sebagai suatu istilah yang lazim digunakan untuk memberi identitas pada bentuk metode dakwah di televisi dimana metode dakwah dikemas dalam bentuk hiburan yang diselingi dengan acara seperti humor, drama, nyanyian maupun informasi-informasi yang ringan. ${ }^{21}$

Berdakwah melalui televisi maka perlu ditata teknik yang tepat dan peningkatan isi atau materi dakwah sesuai dengan kebutuhan masyarakat yang berarti bahwa berdakwah melalui media massa di televisi membutuhkan konsep yang selektif dan terarah untuk masyarakat luas. Oleh karena itu menyampaikan pesan-pesan dakwah di televisi perlu memperhatikan karakteristik media massa. Asep Saiful Muhtadi mengemukakan karakteristik media massa sebagai berikut, pertama, komunikasi massa berlangsung satu arah. Kedua, komunikasinya bersifat melembaga. Ketiga, pesan-pesan yang disampaikan bersifat umum. Keempat, pesanpesan yang disampaikan lewat media digunakan secara serempak. Kelima, komunikasinya bersifat heterogen. ${ }^{22}$

Dakwahtainment sebagai suatu istilah yang lazim digunakan untuk memberi identitas pada bentuk metode dakwah ditelevisi dimana metode dakwah dikemas dalam bentuk hiburan yang diselingi dengan acara seperti humor,drama, nyanyian maupun informasiinformasi yang ringan. Dakwahtainment saat ini semakin semarak dan selalu menghiasi

\footnotetext{
${ }^{19}$ Ilyas Ismail, Paradigma Dakwah Sayyid Qutub: Rekonstruksi Dakwah Harakah (Jakarta: Penamadani, 2006), h. xxvii.

${ }^{20}$ Ilyas Ismail, Paradigma Dakwah Sayyid Qutub: Rekonstruksi Dakwah Harakah, h. 141.

${ }^{21}$ Fatma Laili, Dilema dakwahtainment, , h. 129

${ }^{22}$ Asep Saiful, Jurnalistik Pendekatan Teori dan Praktek (Cet. 1; Jakarta: Logos, 1999), h. 73
} 
layar televisi khususnya di pagi hari dan pada bulan Ramadhan. Dakwah yang terkadang diselingi humor tersebut menjadi komoditas masyarakat sehari-hari. Acara yang kerap dikemas dalam model 'curhat' ini menyedot perhatian masyarakat luas. acara pengajian di televisi sebagai wajah dari kolaborasi anatara dakwah dengan kemajuan teknologi merupakan angin segar bagi perkembangan dunia penyiaran Islam itu sendiri. ${ }^{23}$ Namun kemajuan ini tidak begitu saja mengakhiri perjuangan dakwah Islam begitu saja, karena beriringan dengan maraknya dakwah (pangajian) di telivisi ternyata menuai beragam pro dan kontra terhadap eksistensi acara tersebut yang muncul di tengah persepsi masyarakat.

Dakwahtainment merupakan dakwah yang dikemas sedemikian rupa dengan menghadirkan unsur entertainment yang menjadi satu kesatuan yaitu dakwah yang menghibur Dakwahtainment adalah program siaran yang bernuansa religi yang dikategorikan sebagai si'ar atau dakwah Islam, tetapi sekaligus juga sebagai hiburan. Dakwahtainment adalah produk industri siaran media sebagai pilihan tayangan bernuansa religius untuk pemenuhan kebutuhan spiritualitas seseorang. Menurut Ahmad Atabik yang di kutip oleh Fatma Laili dakwahtainment adalah bentuk dakwah dengan berbagai metode yang di padukan dengan hiburan melalui media televisi.. Dalam hal ini, bentuk dakwah yang dilakukan oleh Sunan Kalijaga yang menggunakan medium wayang dalam berdakwah adalah contoh dari dakwahtaiment ${ }^{24}$

\section{METODOLOGI PENELITIAN}

Penelitian ini mengacu pada penelitian lapangan dengan pendekatan deksriptif kualitatif. Penelitian deskriptif adalah penelitian yang dimaksud untuk mengumpulkan informasi mengenai status suatu gejala yang ada, yaitu keadaan gejala menurut apa adanya pada saat penelitian dilakukan, sehingga hanya merupakan penyingkapan fakta dengan menganalisis data. Pendekatan yang digunakan adalah pendekatan Komunikasi massa dan dakwah. Sumber data yang dimaksud dengan penelitian ini adalah subyek dari mana data diperoleh. Sumber data dalam penelitian ini adalah menggunakan sumber data primer dan sekunder.

a. Data primer adalah data yang diperoleh melalui field research atau penelitian lapangan dengan melakukan interview, yang berarti kegiatan langsung ke lokasi penelitian untuk memperoleh data dari narasumber dengan jumlah 5 informan,

${ }^{23}$ Aris Saefulloh,. "Dakwahtainment: Komodifikasi Industri Media di Balik Ayat Tuhan". Jurnal Komunika. Vol.3 No.2 Juli- Desember 2009, h.112

${ }^{24}$ Fatma Laili, Dilema dakwahtainment, , h. 129 
b. Sumber data sekunder yaitu, data yang berasal dari dokumen, arsip atau buku

\section{Metode Pengumpulan Data}
a. Observasi
b. Wawancara (tidak langsung)
c. Dokumentasi

\section{Teknik Pengolahan dan Analisis Data}

Proses pengolahan data melalui tiga tahap yaitu:

a. Reduksi data

Reduksi data disini yaitu dimana data yang didapatkan dari observasi dan pengamatan lebih lanjut, dilakukan pengelompokan terhadap kategori kategori yang sesuai dengan arah penelitian.

b. Penyajian data

Penyajian data disini mengambil dari data-data yang telah direduksi sebelumnya dan disajikan dalam bentuk deksriptif naratif.

c. Verifikasi data

Peneliti membuktikan kebenaran data yang diperoleh dengan mengadakan triangulasi. Data-data yang telah dianalisis secara saling berhubungan lalu akan dikonfirmasikan dengan informan secara triangulasi.

\section{TANGGAPAN MASYARAKAT DESA WONOREJO TERHADAP DAKWAHTAINMENT ISLAM ITU INDAH DI TRANS TV}

Kemampuan media televisi dianggap efektif dan efisen dalam menyebarakan media dakwah. Alat media audio visual ini sangat berpengaruh dalam sikap dan kepribadian masyarakat secara luas. Jaringan televisi berkembang pesat menjangkau masyarakat hingga pelosok wilayah yang terpencil. Teknologi televisi telah berkembang luas sehingga mampu menciptakan realitas sosial yang menyerupai realitas sebenarnya di masyarakat. ${ }^{25}$ Secara geografis Desa Wonorejo terletak di daerah yang cukup strategis. Berada tidak jauh dari sarana pemerintahan dan kawasan ini tergolong sudah maju. Selain itu, masyarakat desa wonorejo juga dianugerahi berupa tanah yang sangat baik dan subur. Itu terbukti bahwa sebagian besar masyarakat desa menggantungkan hidupnya sebagai petani, dan sukses di bidangnya.

${ }^{25}$ Labib Muhammad, Potret Sinetron Indonesia (Jakarta: PT Mandar Utama Books Division, 2002), h. 15. 
Berbicara kebutuhan akan informasi, seluruh manusia pasti membutuhkan banyak informasi, terkhusus untuk ilbu rumah tangga yang harus mempunyai pengetahuan dan pemahaman yang baik untuk pedoman hidup berumah tangga dan pengawasan terhadap anakanaknya.

Seluruh program acara yang ditayangkan di televisi tentunya memberikan banyak informasi, hanya terkadang informasi tersebut ada yang kurang berkualitas. Saat ini kebanyakan acara televisi hanya menyajikan informasi yang bersifat menghibur saja yang sangat kurang nilai edukasinya. Bahkan, dalam sebuah tayangan televisi masih sangat kurang sekali yang menayangkan acara yang bernilai edukasi dan menghibur.

Berdasarkan hasil wawancara, observasi, dan dokumentasi yang peneliti lakukan di Desa Wonorejo Kecamatan Mangkutana Kabupaten Luwu Timur. Berikut ini merupakan deskripsi tanggapan dari masyarakat Desa Wonorejo Kecamatan Mangkutana Kabupaten Luwu Timur. Tanggapan masyarakat terhadap program siaran dakwahtainment "Islam Itu Indah di Trans TV".

Sumarni menilai program siaran dakwahtainment Islam itu indah sangat bagus dan ceramah yang di bawakan berkaitan dengan kehidupan sehari-hari sangat disarankan untuk ibu-ibu rumah tangga sembari mengisi kekosongan. Saya rutin menonton di pagi hari sebelum memulai aktivitas saya menambah ilmu dan wawasan saya tentang ajaran agama sebagai istri yang shaleha agar saya dapat mendidik dan membina anak-anak saya menjadi anak shaleh dan shaleha". ${ }^{26}$

Penyajian materi dakwah Islam Itu Indah sangat membantu masyarakat terkhusus Ibu-ibu rumah tangga dalam mempelajari dan memahami ajaran agama dan syariat Islam terutama dalam mendidik anak.

Sri Rahayu menilai program dakwah yang disampaikan cukup bagus sangat bermanfaat untuk menambah pengetahuan. Membahas tentang Islam yang lebih mendalam, tetapi karena hiburan/guyonan yang lebih dominan memungkinkan masyarakat hanya menonton tayangan islam itu indah sebagai hiburan saja tanpa mendapat manfaat dari yang ditayangkan. "Acara dakwahnya bagus dan sangat bermanfaat bagi masyarakat utamanya yang minim pengetahuannya tentang Ajaran agama islam, namun harus lebih mengimbangi antara materi dakwah dengan hiburan/guyonan". ${ }^{27}$

${ }^{26}$ Sumarni (43 tahun ), Ibu Rumah Tangga, "Wawancara", Desa Wonorejo, 23 Oktober 2018.

${ }^{27}$ Sri Rahayu ( 23 tahun ), Ibu Rumah Tangga, “Wawancara”, Desa Wonorejo, 19 Oktober 2018. 
Respon informan mengenai program siaran dakwahtainment Itu Indah sudah bagus, karena kesibukan informan maka tidak terlalu menarik kesimpulan dari segi kebutuhannya karena informan menonton sebagai hiburan saja.

Mujiati Ibu rumah tangga) menilai bahwa siaran Islam Itu Indah sangat menarik dan temanya sangatlah bagus sesuai perkembangan zaman. Dan adanya Segment tanya jawab yang lebih mendalam sehingga memperjelas subtansi-subtansi masalah yang ada di masyarakat. "saya suka saat segmen tanya jawab dimana saya dapat mengetahui persoalan-persolan khususnya ketika kita berumah tangga hal-hal negatif yang harus dicegah seperti perselingkuhan dan kekerasan di dalam rumah tangga. Ujarnya dengan lugas". ${ }^{28}$

Dari pernyataan tersebut, masyarakat memilki kebutuhan khusus dalam memahami tema yang disampaikan oleh Ustadz M. Nur Maulana dan pesan moral yang berkembang di masyarakat.

Dari hasil wawancara tentang pemilihan tema dalam program siaran dakwahtainment "Islam Itu Indah" di Trans TV, maka diperoleh hasil wawancara sebagai berikut :

Sumarni menilai tema yang digunakan pada siaran dakwahtainment Islam itu indah sangat fresh dan unik dan sederhana sehingga mudah di pahami. "Pemilihan judul dan tema sangat bagus karena membahas keindahan-keindahan sehingga saya sebagai penonton merasa terhibur dan dengan penyampaian seperti itu membuat kita tidak bosan". 29

Dari pernyataan di atas Informan merasa terhibur dan tertarik dengan tema dan cara penyampaian materi dakwah yang disajikan. Sri Rahayu (Staff kearsipan Desa Wonorejo) menilai pemilihan tema sudah sesuai dengan kebutuhan dan fenomena yang ada di kehidupan masyarakat.

“Temanya sudah bagus sangat cocok dengan materi dakwah yang disampaikan". 30

Dari pernyataan tersebut masyarakat merasa terhibur dan tertarik dengan tema dan cara penyampaian materi dakwah yang disajikan. Ibu Sartini (Ibu rumah tangga) menilai bahwa tema yang digunakan sudah bagus dan mengikuti perkembangan zaman, sehingga bukan hanya kalangan orang tua remaja pun sudah tertarik untuk menonton.

\footnotetext{
${ }^{28}$ Mujiati ( 44 tahun), Ibu Rumah Tangga, "Wawancara”, Desa Wonorejo, 20 Oktober 2018.

${ }^{29}$ Sumarni (43 tahun ), Ibu Rumah Tangga, "Wawancara”, Desa Wonorejo, 23 Oktober 2018.

${ }^{30}$ Sri Rahayu (23 tahun), Ibu Rumah Tangga, “Wawancara”, Desa Wonorejo, 19 Oktober 2018.
} 
"Temanya sudah bagus dan mengikuti perkembangan zaman sehingga anak saya yang berumur 14 tahun sangat suka menonton, setiap hari libur saya rutin mengawasi anak saya ketika menonton, karena biasa akhirnya anak saya rutin menonton, temanya tidak berat sangat sederhana". 31

Dari hasil wawancara di atas dapat disimpulkan tema yang disajikan sangat menarik perhatian bukan hanya orang tua saja yang menonton namun hingga kalangan remaja.

Dari pernyataan di atas dapat disimpulkan tema dan materi dakwah yang disajikan sangat sudah mendasar fungsinya yaitu fungsi televisi secara yaitu fungsi penerangan, fungsi pendidikan dan fungsi hiburan.

Ibu Astati (Ibu rumah tangga) cukup baik karena ustadz M. Nur Maulana memiliki cara yang unik untuk menarik penontonnya dengan sapaan khasnya.

Ibu Mujiati ( Ibu rumah tangga ) gayanya menarik tapi agak lebay jadi mengurangi wibawa ustadnya.

Dari hasil pengumpulan data program siaran dakwahtainment Islam Itu Indah sudah ada keseimbangan aspek-aspek didalam dakwah yaitu aspek pemberi peringatan ( tandzir ) yang berarti materi dakwah yang disampaikan secara tepat dengan aspek (tabsyir) memberi kabar gembira dalam arti penyampaian materi dakwah dengan cara santai dan melalui guyonan/hiburan yang masih dalam tatanan amar ma'ruf nahyi mungkar yaitu kesesuaian antara materi yang disampaikan dan hiburan yang diberikan.

Tanggapan masyarakat program siaran dakwahtainment Islam Itu Indah segment yang paling disukai adalah segment tanya jawab karena pada segment itu mad'u mendapatkan pengetahahuan yang lebih karena sasaran objek dakwahnya bisa mengena keseluruh bidang yang dapat memunculkan masalah dan cara penyelesaiannya. Dan segment yang paling tidak disukai adalah segment doa karena terkesan sangat buat-buat dan terlalu lebay sehingga tampilannya sangat tidak nyata. Disini komunikan atau mad'u berhak memilih tayangan yang dia sukai.

\section{Faktor-faktor yang mendorong masyarakat untuk menyaksikan program dakwahtainment Islam Itu Indah di Trans TV.}

Faktor-faktor yang mendorong masyarakat untuk menyaksikan dakwahtainment melalui program siaran "Islam Itu Indah" di Trans TV kebanyakan karena cara penyampaian Ustadz Maulana. Masyarakat Desa Wonorejo sering menonton program siaran "Islam Itu Indah" di Trans TV dikarenakan tertarik pada tema yang disajikan dalam program siaran tersebut.

\footnotetext{
${ }^{31}$ Sartini (39 tahun), Ibu Rumah Tangga, “Wawancara”, Desa Wonorejo, 23 Oktober 2018.
} 
Pemilihan tema yang tepat sangat mempengaruhi tercapainya tujuan dakwah. Tujuan dakwah dapat tercapai dengan beberapa usaha yang harus dilakukan oleh $d a$ ' $i$. Yang dimaksud tema yang menarik adalah tema yang sesuai dengan keinginan dan kebutuhan pemirsanya termasuk masyarakat Desa Wonorejo.

Pada dasarnya, keinginan dan kebutuhan masyarakat terhadap dakwah sangatlah besar, namun yang sangat menarik dan dibutuhkan masyarakat adalah tema-tema yang berkaitan dengan kehidupan sehari-hari yang berhubungan dengan akhlakul karimah seperti contohnya tema yang berkaitan dengan akhlakul karimah yaitu pentingnya membina hubungan baik antar tetangga, keluarga, menghormati orang tua, dan lainnya.

Metode dakwah yang global itu meliputi hikmah, metode al-maudhah al hasanah ( Nasehat yang baik ) dan metode mujadalah ( metode diskusi ). Hal ini memberi peluang bagi seorang $d a$ 'i untuk mengembangkan dan memberi peluang modifikasi cara berdakwah sesuai perkembangan zaman. Itulah yang dilakukan ustadz ndah di Trans TV.

Faktor yang mempengaruhi minat menonton masyarakat adalah waktu tayang program siaran yang berduirasi 60 menit itu ditayangkan setiap hari pada pukul 05.00-06.00. karena pada waktu tayang itu merupakan daya tarik tersendiri untuk menonton setelah melaksanakan shalat subuh dan tidak ada kegiatan yang dilakukan hingga sebagian masyarakat memanfaatkan untuk menonton program siaran tersebut sebelum memulai aktivitasnya.

Hasil wawancara faktor-faktor yang mendorong masyarakat untuk menyaksikan program dakwahtainment Islam Itu Indah di Trans TV, dari hasil wawancara dari informan menunjukkan:

Sumarni (Ibu pengajian Babuttaubah Sendang Rejo) cara penyampaian materi dakwah ustad M. Nur Maulana sangat menarik dan juga mudah dipahami.

"Saya sangat tertarik dengan gaya bahasa ustadz M. Nur Maulana ketika menyampaikan materi dakwah karena sangat menarik dan mudah dipahami”. ${ }^{32}$

Dari pernyataan di atas tema yang disajikan sangat menarik pemirsanya dengan zaman sekarang, keinginan dan kebutuhan masyarakat terhadap dakwah sangatlah kompleks dengan tema-tema yang berhubungan dengan kehidupan sehari-hari yaitu akhlakul karimah.

Mujiati (Ibu rumah tangga) cara penyampaian ustadz Maulana, unik dan menarik, dan tema-tema yang dibawakan sangatlah komplek tetapi tema yang paling banyak diinginkan adalah tema-tema yang berhubungan dengan kehidupan sehari-hari. "karena

${ }^{32}$ Sumarni (43 tahun ), Ibu Rumah Tangga, “Wawancara”, Desa Wonorejo, 23 Oktober 2018. 
tema dan materi yang disampaikan sangat menarik dan sesuai dengan kehidupan berumah tangga, Saya senang menonton karena ustadnya lucu". ${ }^{33}$

Dari pernyataan di atas tema dan materi dakwah yang disajikan program siaran Islam itu indah menarik pemirsanya termasuk Ibu rumah tangga. Pemilihan tema yang tepat sangat mempengaruhi tercapainya tujuan dakwah.

Hasil penelitian ini telah sejalan dengan landasan teori kognitif sosial dimana dalam penelitian ini terbagai hal tujuan yang akan dicapai yakni pengamatan, efek larangan, dan efek suruhan. Dimana dalam hal ini menyangkut efek media yang ditonton adalah dampak yang ditimbulkan ketika menonton. Sisi apa yang diambil dari menonton tayangan televisi.

\section{E. KESIMPULAN}

Tanggapan Masyarakat Desa Wonorejo menilai bahwa tema yang digunakan sudah bagus dan mengikuti perkembangan zaman lebih tertarik pada materi dakwah yang bersifat akhlakul karimah dengan pembawaan materi yang ringan dan sederhana. materi tersebut lebih banyak di jumpai dalam kehidupan sehari-hari .

Faktor-faktor yang mendorong masyarakat untuk menyaksikan program dakwahtainment Islam Itu Indah di Trans TV. enyampaian materi dakwah ustad M. Nur Maulana sangat menarik dan juga mudah dipahami, tema yang disajikan sangat menarik pemirsanya dengan zaman sekarang, keinginan dan kebutuhan masyarakat terhadap dakwah sangatlah kompleks dengan tema-tema yang berhubungan dengan kehidupan sehari-hari yaitu akhlakul karimah.

${ }^{33}$ Mujiati ( 44 tahun), Ibu Rumah Tangga, "Wawancara”, Desa Wonorejo, 20 Oktober 2018. 


\section{DAFTAR PUSTAKA}

Abdullah, Boedi, Metode Penelitian Ekonomi Islam Muamallah.

Arikunto, Suharsimi, Prosedur Penelitian Suatu Pendekatan Praktek, (Jakarta: 1992).

Al Qadri, Syarif "Pengaruh Menonton Drama Korea di Indosiar Terhadap Perilaku Imitasi Pada Remaja di Kelurahan Benteng Selatan Kecamatan Benteng Kabupaten Kepulauan Selayar”.,Skripsi (Makassar : Fakultas Dakwah dan Komunikasi,2013

Barker, Chris Cultural Studies Teori dan Praktik, Terj. Nurhadi (Yogyakarta: Kreasi Wacana, 2006).

Bounnanoo, Milly, The Age of Television Experiences and Theories. Book Review by John Hartly. (International Journal of Communications: 2009

Departemen Agama, Al Quran dan Terjemahannya, (Semarang, Toha Putra, 2007).

Ismail, Ilyas, Paradigma Dakwah Sayyid Qutub: Rekonstruksi Dakwah Harakah (Jakarta: Penamadani, 2006

Kellner, Douglas, Media Culture: Cultural Studies, Identity anPolitics between The Modern and Postmodern (New York: Routledge, 1995).

Kusnawan, Aep, Komunikasi Penyiaran Islam Cet. I; Bandung: Benang Merah Press, 2004.

Kuswandi, Wawan, Komunikasi Massa Sebuah Analisis Media Televisi.

Kementrian Agama RI, Al Quran dan Terjemahnya dilengkapi dengan Ashabun Nuzul dan Hadits Shahih, Bandung : PT Sygma examedia Arkanleema, 2014.

Laili, Fatma, "Dilema dakwahtainment", jurnal Komunikasi Penyiaran Islam Tabsyir, Vol.I.No.I tahun 2013 (STAIN Kudus, 2014

Moleong, J. Laxi, Metode Penelitian Kualitatif (Bandung: Remaja RosdaKarya, 2002.

Mulyana,Deddy, Ilmu Komunikasi Suatu Pengantar. Bandung: Remaja Ros Dakarya, 2000

McQuail, Dennis, Teori Komunikasi Massa,Terj. Agus Dharma dan Aminuddin Ram (Jakarta: Erlangga, 1987

Morissan. Manajemen Media Penyiaran, Strategi Mengelola Radio dan Televisi. (Jakarta: Kencana, 2008).

Morissan, M.A. Teori Komunikasi Massa (Bogor: Penerbit Ghalia Indonesia, 2013

Muhammad, Labib, Potret Sinetron Indonesia (Jakarta: PT Mandar Utama Books Division, 2002

Onong Uchajana Effendy. Televisi Siaran Teori dan Praktek. ( Bandung: Mandar Maju, 1993).

Rahmat, Jalaluddin, Psikologi Komunikasi. (Bandung: Remaja Rosdakarya, 2001).

Solissa, A Basir, Kemajuan Barat dan Reaksi Dunia Islam Dalam Pandangan Hasan Tibbi," “Jurnal Refleksi", Vol. 2, No. 2, (Juli 2002).

Saefulloh, Aris, "Dakwahtainment: Komodifikasi Industri Media di Balik Ayat Tuhan". Jurnal Komunika. Vol.3 No.2 Juli- Desember 2009.

Saiful, Asep, Jurnalistik Pendekatan Teori dan Praktek (Cet. 1; Jakarta: Logos, 1999).

Suhandang, Kustadi, Manajemen Pers Dakwah: Dari Perencanaan Hingga Pengawasan, (Cet. I; Bandung: Marja, 2007). 
Sulthon, Muhammad, Menjawab Tantangan Zaman; Desain Ilmu Dakwah; Kajian Ontologis, Epistemologis dan Aksiologis, (Yogyakarta: Pustaka Pelajar, 2003). 